\title{
Changes in thyroid ultrasound during the first trimester of pregnancy are not related to levels of TSH
}

Susana Pérez Naranjo, Ángel Merchante Alfaro. Olalla Rubio Puchol, Pablo Abellán Galiana, Pilar Cubells Cascales, Roser Querol Ripoll. Departamaent of Endocrinology and Nutrition. University General Hospital of Castellon.

\section{INTRODUCTION}

- The changes observed in thyroid ultrasound during pregnancy are related to the nutritional status of iodine, but its association with TSH levels or the presence of thyroid peroxidase antibodies (TPOAb) is unclear

\section{OBJETIVE}

- To compare the relationship between the findings in thyroid ultrasound and thyroid function tests in the first trimester of pregnancy in an iodine sufficient area.

\section{SUBJECTS AND METHODS}

- We conducted an observational cohort study and included 205 pregnant women (mean age $32.9 \pm 5.0$ years) in the 1 (st) trimester, recruited from universal screening. We performed a nutritional survey and we measure urinary iodine, TSH, free T4, free T3 and TPOAb. Through a thyroid ultrasound we evaluate the thyroid volume, ultrasound textura and the number and size of thyroid nodules. We performed the comparison between the different variables according to their levels of TSH, and established three subgroups: TSH $\leq$ $2.5,2.6-4$ and $>4 \mathrm{mU} / \mathrm{l}$, with 65,70 and 70 pregnant women in each group respectively.

\section{RESULTS}

- We found no statistically significant differences between pregnant women by levels of TSH in age, urinary iodine, percentage of positive TPOAb, thyroid volume, thyroid texture, and number of nodules. The pregnant woman with higher TSH levels had higher BMI, higher levels of free T4, higher titers of TPOAb and increased consumption of iodized salt. In the univariate analysis only the presence of positive TPOAb (and not the presence of elevated TSH levels) was associated with the presence of goiter ( $r=0,26$; $p<$ $0.01)$ and heterogeneous echotexture $(r=0.72 ; p<0.001)$.

\begin{tabular}{|c|c|c|c|}
\hline \multirow[t]{2}{*}{ Variables } & \multicolumn{3}{|c|}{ TSH levels } \\
\hline & $\leq 2,5 \mathrm{mUI} / \mathrm{L}$ & 2,5-4 mUI/I & $\geq 4 \mathrm{mUl} / \mathrm{l}$ \\
\hline $\begin{array}{l}\text { Age(years) } \\
\text { mean SD }\end{array}$ & $32,3 \quad 4,3$ & $33,54,6$ & $33,1 \quad 5,9$ \\
\hline Goiter, n (\%) & $2(3,1 \%)$ & $2(2,9 \%)$ & $2(2,9 \%)$ \\
\hline $\begin{array}{c}\mathrm{VT}(\mathrm{ml}) \\
\text { mean SD }\end{array}$ & $9,6 \quad 3,7$ & $9,13,0$ & $8,8 \quad 3,4$ \\
\hline $\begin{array}{c}\mathrm{UIC}(\mu \mathrm{g} / \mathrm{l}) \\
\text { median IQR }\end{array}$ & $190,2349,1$ & $190,1253,8$ & $196,1 \quad 194,1$ \\
\hline $\begin{array}{l}\mathrm{TSH}(\mathrm{mUl} / \mathrm{l}) \\
\text { mean SD }\end{array}$ & $1,44 \quad 0,54$ & $3,21 \quad 0,46$ & $5,52 \quad 1,65$ \\
\hline $\begin{array}{l}\mathrm{T} 4 \mathrm{l}(\mathrm{ng} / \mathrm{dl}) \\
\text { mean SD }\end{array}$ & $0,66 \quad 0,18$ & $0,75 \quad 0,17$ & $0,71 \quad 0,12$ \\
\hline $\begin{array}{c}\text { TPOAb + } \\
\text { n (\%) }\end{array}$ & $12(18,5 \%)$ & $18(25,7 \%)$ & $14(20 \%)$ \\
\hline $\begin{array}{c}\text { Ecoestructura } \\
\text { tiroidea } \\
\text { heterogénea } \\
\mathrm{n}(\%)\end{array}$ & $6(9,2 \%)$ & $9(12,9 \%)$ & $11(15,7 \%)$ \\
\hline $\begin{array}{c}\text { Number nodules } \\
n \text { (\%) }\end{array}$ & $7(10,8 \%)$ & $7(10 \%)$ & $8(11,4 \%)$ \\
\hline
\end{tabular}

Table 1: Descriptive analysis of the variables in pregnant according to TSH levels

\begin{tabular}{|c|c|c|c|c|}
\hline \multirow[t]{2}{*}{ Variables } & \multicolumn{3}{|c|}{ TSH levels } & \multirow[b]{2}{*}{$P$} \\
\hline & $\leq 2,5 \mathrm{mUI} / \mathrm{L}$ & 2,5-4 mUl/l & $\geq 4 \mathrm{mUl} / \mathrm{l}$ & \\
\hline $\mathbf{n}$ & 65 & 70 & 70 & \\
\hline $\mathrm{TSH}(\mathrm{mUl} / \mathrm{l})$ & $1,44 \pm 0,54$ & $3,21 \pm 0,46$ & $5,52 \pm 1,65$ & $<0,001^{*}$ \\
\hline $\mathrm{T} 4 \mathrm{I}(\mathrm{ng} / \mathrm{dl})$ & $0,66 \pm 0,18$ & $0,75 \pm 0,17$ & $0,71 \pm 0,12$ & $<0,001^{*}$ \\
\hline BMI $\left(\mathrm{Kg} / \mathrm{m}^{2}\right)$ & $23,0 \pm 1,9$ & $23,5 \pm 1,1$ & $24,1 \pm 2,7$ & $0,03^{*}$ \\
\hline $\begin{array}{c}\text { TPO Ab (UI/L) } \\
\text { (titers) }\end{array}$ & $15,8 \pm 53,9$ & $57,7 \pm 167,5$ & $52,4 \pm 153,7$ & $0,055^{*}$ \\
\hline $\begin{array}{c}\text { Consumption } \\
\text { iodized salt } \\
\text { n (\%) }\end{array}$ & $29(44,6 \%)$ & $50(71,4 \%)$ & $48(68,6 \%)$ & $0,004^{*}$ \\
\hline
\end{tabular}

Table 2: Statistically significant variables in pregnant according toTSH levels

\begin{tabular}{|c|c|c|}
\hline & Positive TPOAb & $P$ \\
\hline Goiter & $\mathrm{R}=0.26$ & $<0,01$ \\
\hline $\begin{array}{c}\text { Heterogeneous } \\
\text { echotexture }\end{array}$ & $\mathrm{R}=0,72$ & $<0,001$ \\
\hline
\end{tabular}

Table 3: Univariate analysis betwen positive TPOAb and goiter and heterogeneous echotexture

\section{CONCLUSIONS}

\begin{abstract}
- We found no significant differences in the nutritional status of iodine, in the thyroid volume, in the prevalence of goiter or nodule prevalence in pregnant women according to their levels of TSH. Ultrasound abnormalities found in the first trimester of pregnancy appear to be linked with the presence of TPOAb..
\end{abstract}

